\title{
TRABALHO DOCENTE: A CRISTALIZAÇÃO DE UMA METÁFORA
}

\author{
THE WORK OF TEACHING:THE CRYSTALLISATION OF A METAPHOR
}

TRABAJO DOCENTE: LA CRISTALIZACIÓN DE UNA METÁFORA

Gideon Borges dos Santos ${ }^{1}$

Resumo A exigência de lidar diretamente com a subjetividade faz com que a educação apresente características muito peculiares, que desbordam os limites de qualquer organização lógica. Este ensaio põe no centro de suas reflexões os limites da metáfora do trabalho na educação, em sua função de modelar e, assim, explicar a atividade docente. Como doadora de sentido universal para as atividades humanas, a metáfora do trabalho, que não se reduz ao simples deslocamento de palavra, mas à transposição de um sentido enraizado, tornou-se excessiva e insuficiente para se pensar a tarefa da formação humana. Nesse sentido, a introdução do conceito de ação para elucidar a atividade docente surge com potencial representativo para a prática do professor, ali onde a metáfora do trabalho não consegue realizar plenamente.

Palavras-chave metáfora; trabalho; docência.
Abstract The requirement of dealing directly with subjectivity brings very peculiar characteristics to education that go beyond the limits of any logical organization. This article focuses on the limits of the metaphor of work in education, on its function of modeling and, thus, explaining the teaching activity. As a donor of a universal sense to human activities, the metaphor of work, which cannot be reduced to the simple displacement of words, rather to the transposition of ingrained sense, became excessive and insufficient to consider the task of human development. In this sense, the introduction of the concept of action to elucidate the teaching activity comes up with representative potential for the practice of the teacher, a place where the work metaphor cannot be fully realized. Keywords metaphor; work; teaching. 


\section{Introdução}

A predominância, explícita ou velada, da perspectiva que faz do trabalho o conversor universal para apreciação e valorização das atividades humanas criou poucas oportunidades para que se fizesse a crítica das reduções a que a atividade de formação veio sendo, ao menos teoricamente, submetida nas últimas décadas. Tomada como doadora de sentido para as atividades humanas, a metáfora do trabalho se ocupou em modelar a atividade docente a partir do trabalho industrial, para que os professores pudessem conquistar maior 'autonomia', sem necessariamente expressar os limites e as consequências que essa determinação traria para a escola e para a atividade do professor. É claro que as metáforas providenciam, assim, os apoios sensíveis e afetivos sem os quais nenhuma representação racional pode fazer sentido. Mas não submetida ao exercício da crítica, qualquer metáfora pode se tornar excessiva e insuficiente: excessiva porque uma metáfora não se reduz ao simples deslocamento da palavra, à aplicação terminológica, mas realiza a transposição de sentidos; e insuficiente na medida em que tais sentidos se enrijecem, se cristalizam, levando ao uso automático das palavras e ao lugar-comum do que antes era promessa de transgressão.

Obviamente, nenhuma metáfora esgota os sentidos do magistério, da escola e da formação humana. E isso não significa que não se deva - como se fosse sequer possível - recorrer a metáforas. Contudo, seu emprego não é anódino: sempre há, no ato de aproximação de duas coisas, uma intenção e um custo. Exposta a um uso irrefletido e abusivo, qualquer metáfora torna-se o oposto do que um dia foi; é preciso cuidar para que ela não se torne independente, alienando o uso reiterado da nossa capacidade de deliberação e de crítica. Cabe, pois, escolher bem suas metáforas e mantê-las sempre sob suspeição: o que a metáfora do trabalho introduz na análise da formação humana? Que sentidos e realidades ela aproxima e quais as consequências dessa aproximação? Sem a pretensão de esgotamento, este ensaio é resultado de uma pesquisa de doutoramento. Objetiva fornecer alguns elementos que possam vir a alimentar a reflexão sobre as metáforas do trabalho na educação e os limites que elas apresentam, para elucidar a tarefa de educar os homens naquilo que essa atividade pode se mostrar como própria. Não que se acredite que a crítica racional é por si só capaz de desconstruir esquemas mentais fortemente arraigados na tradição e nas práticas culturais. Longe de tomá-la como uma fatalidade, esperamos que, submetida à reflexão teórica, a metáfora do trabalho na educação possa realizar plenamente sua vocação heurística; e diante do inevitável desgaste que seu uso abusivo por tantas vezes acarreta, esperamos igualmente que ela possa nos ensinar o desapego intelectual de que vive o pensamento (Valle, 2008). 


\section{A metáfora e a transposição do sentido}

Na tradição ocidental, Aristóteles foi o primeiro a pensar filosoficamente a metáfora como um artifício na Retórica e na Poética (Ricœur, 2000). Em sua função retórica, o tropo está relacionado à própria vida democrática: a valorização da eloquência e dos artifícios do discurso se deve à importância que a persuasão passou a desempenhar na vida política. A metáfora como deslizamento de sentidos é um artifício do bem-dizer, e a finalidade do discurso é influenciar o povo nas assembleias. A taxionomia das figuras de linguagem que a Retórica estabelece tem por objetivo controlar uma prática pública que, para Aristóteles, corria o risco de degenerar-se em simples "uso selvagem das palavras" (Ricœur, 2000, p. 19). O perigo do belo discurso reside em entusiasmar os sentidos e esvaziar o pensamento. Em contrapartida, o benefício é o enorme poder amealhado, em uma democracia, para todo aquele que sabe manipular as palavras para seduzir os homens.

Esse caráter cosmético da metáfora revela-se, porém, bem diferente na arte poética. Ali, o discurso assume um papel distinto, o de produzir a catarse: por isso, na tragédia, a metáfora não é apenas recurso estilístico, mas, se assim se pode dizer, operação psicológica que permite aos espectadores se reconhecerem naqueles que são representados por via da mimese, da ficção, do mito, da fábula e da fantasia.

Em sua definição mais geral, a metáfora consiste na transferência de sentido entre palavras ou, como definiu Aristóteles (1975, p. 211), a "transposição do nome de uma coisa para outra". Assim, um termo é arrancado de seu uso corriqueiro e transplantado para outro terreno, mas sempre carregando consigo parte de seu sentido original. O uso "estranho das palavras" para designar coisas diferentes, como a ele se referiu Ricœur (2000, p. 41), promove uma abertura (ampliação) do sentido que se quer dar à coisa nominada. Impregnadas de história, contaminadas pelos usos públicos e privados a que se expuseram, as palavras trazem de uma só vez para o pensamento uma polissemia de sentidos. Até certo ponto, elas são gramaticalmente determinadas, impondo exigências quanto ao seu emprego. Mesmo assim, o uso morfossintático correto das palavras não é suficente para expressar o significado e sentido desejados. Nesse caso, ao promover uma aproximação linguística entre objetos com representações até então distintas, a metáfora não somente rompe com o uso original de uma palavra, mas também permite a expressão de uma ideia pouco conhecida ou de difícil compreensão: a linguagem figurativa permite anunciar aquilo que ainda não pôde se expressar inteiramente pela razão, mas que já se apresenta de alguma forma ao campo intuitivo.

Embora não haja quem não se utilize de metáforas cotidianamente, na ciência clássica seu uso é criticado, em razão, justamente, da imprecisão que 
engendra: "Se as palavras têm mais de um sentido, seu uso na ciência admite somente um" (Ricœur, 2000, p. 66). Assim, os defensores da objetividade científica sustentam que a linguagem figurativa deve ser abandonada para evitar interpretações polissêmicas, ambíguas e equivocadas. Entretanto, é claro que a pura objetividade é uma ilusão, oriunda dos ideais controladores da ciência moderna; e uma linguagem inteiramente objetiva é uma impossibilidade, que dependeria não apenas da completa racionalização da realidade, mas igualmente de uma fantasiosa redução da expressão humana a um código tão restrito e limitado que acabaria por nada mais expressar.

No intuito de oferecer à nossa reflexão um pano de fundo crítico, pareceu-nos importante examinar as metáforas de formação que revelaram, ao longo da história, grande poder de impregnação, fazendo do magistério um sacerdócio, da professora a tia, do professor um especialista e, finalmente, um trabalhador. Estas metáforas expressam para a educação mais do que diferentes significados atribuídos nos diversos contextos sócio-históricos: registram, igualmente, a trajetória de uma prática social instituída, que acompanha pari passu as transformações sociais.

Fortemente enraizada na tradição cristã, a metáfora do sacerdócio introduz uma concepção de formação entendida como uma atribuição divina: aí a lógica da formação extrapola a esfera dos assuntos humanos - como se da atividade de educar fossem arrancadas as suas "raízes permanentes num mundo dos homens ou das coisas feitas pelos homens" (Arendt, 1987, p. 31). O professor é visto como instrumento de realização de um fim que está previamente definido. Neste aspecto, prolonga-se apenas o que a noção de natureza havia recoberto na Antiguidade.

Decerto, nessa concepção, a autoridade do professor é inviolável, digna de respeito absoluto; mas isso apenas porque e enquanto ela representa simbolicamente a própria autoridade divina. Fundada em um poder que se manifesta para além do mundo das aparências, a prática de educação ratifica a hegemonia ideológica de uma razão intemporal, deixando de fora a dimensão política da educação como patrimônio comum. Tomada como atributo divino, a atividade de educar é, portanto, um acontecimento natural elevado ao grau de supranatureza, que contém em si o impulso de seu próprio movimento, que se dá independentemente da deliberação humana e cuja finalidade está determinada desde sempre e de uma vez por todas.

Condenada a se dar como repetição do mesmo, a formação humana não comporta qualquer introdução do novo: nesse contexto, a imprevisibilidade é dada como falha, como ignorância ou como erro. Quanto à pluralidade, ela desaparece para dar lugar à diferença - que faz com que uns realizem mais plenamente do que outros o que a providência divina reservou para a espécie.

A metáfora familiar, pela qual a professora é identificada à tia, também oblitera o sentido político da educação. Aqui, igualmente, o apoio da autori- 
dade pedagógica é buscado na força de impregnação das instituições tradicionais (igreja e família) em uma sociedade conservadora. Mas, diferentemente do sacerdote, a imagem da tia expressa a caracterização social de uma atividade eminentemente feminina, definida como prolongamento do papel que, na vida privada, é reservado à mãe. A indistinção entre a vida privada e a vida pública se realiza no caráter natural que se atribui à formação - tanto quanto a metáfora do pai, espelhada na figura do líder político, naturaliza o poder político identificando-o àquele que Aristóteles bem definia como “despótico" (Arendt, 1987, p. 11).

A naturalização das atividades diretamente relacionadas à definição do modo de ser humano - a política e a educação - implica o obscurecimento do que nelas está em jogo. O poder familiar é mudo e prescinde de justificação. Ora, como insiste Arendt (1987, p. 60), o espaço comum é, ao contrário, marcado pela exigência da visibilidade: só assume existência entre os humanos aquilo que, emergindo do "espaço das sombras", da esfera privada, pode ser exibido no espaço público.

É contra essa perspectiva de naturalização da formação que se investiram as imagens racionalistas da educação. Buscando desvincular-se da imagem de uma educação fundada em princípios tradicionais, a metáfora do professor como especialista em educação se manifestou, inicialmente, no projeto de modernização nacional, erigido nas bases do progresso técnico e científico e do desenvolvimento das chamadas 'ciências da educação'. Assim, a imagem do especialista fez a passagem das metáforas tradicionais para as novas exigências introduzidas pela sociedade capitalista: enquanto nas primeiras era predominante a ideia da educação como acontecimento natural, nas últimas buscou-se vincular a formação humana a uma atividade racional e racionalizada.

Concedendo, portanto, maior objetivação à formação humana, a metáfora do especialista acabou, porém, por introduzir a conversão da educação à lógica do trabalho. Foi do projeto de construção de uma cidadania compatível com o novo ideário republicano, sobretudo a partir das décadas de 1920 e 1930, que resultaram, por força da influência do capitalismo nascente, as primeiras iniciativas de conversão do aluno em produto do 'trabalho' docente. Do ponto de vista da concepção antropológica, as consequências dessa conversão não foram muito diferentes daquelas a que conduzia a tradição conservadora: em todos os casos, o aluno permanecia o objeto de uma ação que, fundada em Deus, na natureza ou na razão, propunha-se a modelá-lo segundo um projeto predefinido. Em todos os casos, o (bom) professor se mantinha como aquele que deveria, antes de qualquer outra coisa, conduzir ao modelo de (bom) aluno, e prevenir-se escrupulosamente contra qualquer elemento de surpresa, que fugisse ao controle, no processo educativo. 


\section{Operários da educação}

No Brasil, mas não somente aqui, a metáfora do professor como um operário foi fortemente influenciada pela ação sindical. Além disso, vários estudos sobre a atividade docente feitos nas décadas de 1980 e 1990, acusando o Estado e suas políticas de servirem a interesses dominantes em escala internacional, ratificaram e fortaleceram ainda mais a identificação dos professores com os operários. Reconhecendo-se como parte integrante da classe trabalhadora, os professores teriam maior 'legitimidade' e 'força' para lutar contra o Estado: maior força porque assim eles estariam unidos em torno de um sindicato; e maior legitimidade porque eram as organizações sindicais as instituições que, na época, se consolidavam como oponentes ao capital. Miguel Arroyo (1980), por exemplo, destaca que a organização da atividade escolar com bases empresariais e a fragilidade da identidade profissional, que punha a docência na linha da marginalidade em relação a outras profissões, foram razões que fizeram com que os professores não se sentissem mais servidores públicos e sim trabalhadores, cuja força de trabalho era vendida a um patrão chamado Estado.

Todavia, não deixa de ser surpreendente o fato de somente a partir da década de 1980 a expressão 'trabalho docente' aparecer de forma recorrente nos textos que tratam do assunto - quando, muito antes disso, termos como 'tarefa escolar', 'trabalho de casa' ou 'tarefa para casa', 'rendimento', 'turno', 'supervisão' e 'direção', também presentes no chão fabril, já eram comuns no vocabulário escolar.

A partir da década de 1980, coroando um projeto que já despontava desde o início do século e cujo objetivo era identificar 'de uma vez por todas' elementos racionais para a atividade docente, o movimento de democratização da escola passou a identificar sistematicamente a formação humana ao trabalho. A metáfora do professor como trabalhador da educação parecia capacitada a indicar a importância que, para a docência, passava a assumir a defesa de melhores condições salariais e de trabalho - anteriormente impossibilitadas pela identificação com as vocações religiosa e materna. Rompendo com o campo semântico em que as antigas metáforas haviam florescido e no qual as noções de vocação, de altruísmo, de sacrifício ganhavam todo o seu sentido, a imagem toda racionalizada do trabalho industrial tornou-se a bandeira de luta da reivindicação por uma educação democrática, pública, gratuita e de qualidade para todos.

Sem negar a importância da objetivação da tarefa da escola pública que garante sua visibilidade e, portanto, seu caráter democrático -, está claro que isso não basta, por si só, para definir o processo formativo (ou, ao menos, quando ele não é reduzido à mera transmissão de conhecimentos ou ao desenvolvimento de habilidades básicas de leitura e escrita). A constru- 
ção para o professor de uma referência quanto à sua identidade profissional e seu papel social se tornou uma evidência: as referências de maior influência sindical irão vindicar para ele o título de 'trabalhador da educação', aproximando os professores dos operários da fábrica.

As aproximações entre a identidade do operário e a identidade do professor e, por conseguinte, entre as atividades de ambos, advindas da equalização ou aproximação pela organização do trabalho, representaram também uma forma de promover a união e a organização dos trabalhadores contra o capital. Entretanto, esse processo não ocorreu sem que se medissem profundamente suas consequências para a organização da atividade do professor. O que faltou a essas análises foi mostrar que, ao se justapor a atividade docente às atividades industriais, pela instituição sindical dos professores, por meio do uso das metáforas do mundo do trabalho e pela criação de um discurso comum capaz de servir de estratégia ao processo de unificação da classe proletária contra o capital, organizou-se a atividade docente com bases similares ao processo industrial.

Dalila Oliveira (2007), por exemplo, destaca as mudanças na atividade docente decorrentes do processo de descentralização administrativa e financeira da educação, padronização dos procedimentos pedagógicos e aumento das responsabilidades - além das atividades de sala de aula, reuniões, planejamento, gestão da escola. A padronização dos processos é um procedimento industrial fabril, especialmente possível, devido ao advento da técnica e à compreensão de certa regularidade fenomênica. Ora, ao mesmo tempo que a autora critica esse processo, pois diz que o tecnicismo da educação decorre de políticas neoliberais, utiliza-se de um discurso que visa promover a unificação dos trabalhadores e, inadvertidamente, colabora para que essa união classista ocorra - e junto com ela a organização de atividades distintas também seja tomada sob o mesmo princípio da lógica fabril.

De igual fatura é o processo de proletarização do professor, introduzido na literatura a partir da década de 1970. Mariano Enguita (1991), por exemplo, o define como movimento pelo qual um grupo de trabalhadores perde, mais ou menos sucessivamente, o controle sobre seus meios de produção, sobre o objetivo de seu trabalho e sobre a organização de sua atividade. Na educação, afirma Enguita, esse processo tem base na perda de autonomia sobre a atividade realizada pelo professor - que, além de ser obrigado a vender a sua força de trabalho, o faz sem exercer controle sobre os processos e produtos de seu trabalho.

(...) A regulamentação do ensino passou, com o tempo, da situação de limitar-se aos requisitos mais gerais para a de prescrever especificações detalhadas para os programas de ensino. A administração determina as matérias que deverão ser dadas em cada curso, as horas que serão dedicadas a cada matéria e os temas em 
que se comporá. Em outras palavras, o docente tem perdido progressivamente a capacidade de decidir qual será o resultado do seu trabalho, pois este já lhe chega previamente estabelecido em forma de disciplinas, horários, programas, normas de avaliação, etc. (Enguita, 1991, p. 48).

A designação do professor como aquele que perdeu o controle dos meios, dos objetivos e do processo de trabalho, definido como processo de proletarização, é criticada por Klater Fontana e Paulo Sergio Tumolo (2008), que recuperam o conceito marxista para dizer que a proletarização relaciona-se com o processo de produção de mais-valia e repartição da sociedade, e não com a degradação das condições de trabalho introduzidas nas escolas pelas políticas educacionais. O termo proletário, insistem os autores, deve ser reservado para distinguir as classes sociais, para definir as divisões sociais segundo a relação com os bens de produção, não devendo ser identificado com a precarização, a intensificação e a deterioração das condições e dos processos de trabalho e com a perda do controle sobre o trabalho, ou mesmo a ausência de um estatuto legalmente reconhecido para a profissão.

Para esses autores, as pesquisas na década de 1990 sobre o 'trabalho docente' se utilizam do mesmo referencial teórico e, possivelmente, do mesmo critério utilizado para análise do trabalhador fabril/industrial. Assim, a 'crescente proletarização na docência' decorre da rápida ampliação do número de professores no setor particular, haja vista a expansão mercantil da educação, em especial nas universidades. Somente os professores das redes particulares de ensino sofrem com o processo de proletarização, porque somente eles produzem valor de troca e mais-valia. Fontana e Tumolo (2008) ainda afirmam que o professor da escola pública, embora venda a sua força de trabalho e produza valor de uso, tal qual o da rede privada o faz, não realiza trabalho produtivo, na medida em que não produz mais-valia.

A análise de Fontana e Tumolo (2008) é bastante esclarecedora, mas ainda presa à ideia de que as imagens do trabalho são universais para se pensar a atividade docente. Entretanto, não deixa de ser curioso que a crítica ao recurso à noção de 'proletarização da docência' não se prolongue na rejeição à imagem do professor operário. Definida como movimento de aquisição da identidade proletária, a proletarização da profissão tende a ser vista como um acontecimento desejável, na medida em que proletário e operário, do ponto de vista dos bens de produção da sociedade capitalista, querem dizer a mesma coisa.

De modo mais geral, porém, os autores identificam a proletarização com a perda de autonomia, manifestada pela fragmentação do trabalho e pela subtração dos meios de controle sobre o trabalho. Em seu sentido histórico, no entanto, a autonomia é um atributo que designa tanto os indivíduos como as sociedades, e que consiste na exigência e na prática de se dar sua 
própria lei (Castoriadis, 1999). A autonomia remete, portanto, a uma dimensão mais ampla, relativa à instituição da sociedade: não se trata de uma 'coisa' que pode ser retirada e colocada, mas algo que se é praticado e que só existe como abertura para a alteridade. Assim, em seu sentido radical, a autonomia se opõe à alienação. Ocorre que os professores vêm sendo acometidos por um acentuado processo de alienação (ou heteronomia), que se define pela não manifestação de iniciativa na realização de sua atividade.

Na presente ideia de similitude entre a atividade da fábrica e a atividade da escola, especialmente na transposição de um termo por outro é que reside um perigo, a cristalização da metáfora. O que antes era somente uma forma de dizer sobre universos que apresentavam supostas semelhanças, ou se instituía a partir de pontos comuns, agora suporta a forma de ser, de modo que realidades distintas passam a ser tratadas como se fossem iguais.

Desse modo, a ideia de representar o professor com o apoio das imagens do operário se torna perfeitamente assimilada quando serve de artifício retórico utilizado para seduzir, para convencer os professores a estabelecerem relação de identidade com a classe trabalhadora. O artifício retórico mantém, no entanto, um compromisso com a sedução: a metáfora do professor como operário e a imagem da fábrica como referências para a escola tornam-se obstáculos para que a escola se pense sobre suas finalidades e para que delibere sobre o tipo de formação que fornece - e mais, sobre bases organizacionais a partir das quais ela quer se fazer. Além disso, essas equivalências tornam possíveis uma organização escolar sob os mesmos princípios da instituição fabril, e ideias como 'produtividade', 'padronização' e 'racionalização' passam também a fazer parte dos objetivos igualmente aplicáveis a esse processo de organização. Somente nos é concebível falar em 'produtividade docente', 'padronização dos métodos de educação' e 'racionalização da atividade de educar' porque foi possível reconhecer a educação como uma 'atividade fabril' e, portanto, passível do mesmo mecanismo de organização a que esta última atividade foi submetida. Isso porque as palavras não são simplesmente usadas no sentido privado, sem um mínimo de relação com o sentido público, porque a linguagem é uma criação social e não um patrimônio do indivíduo.

Exatamente por serem públicas, diz Lílian do Valle (2008) ao citar Castoriadis, as palavras são sentido instituído, nunca vêm soltas, mas são como partes que, arrancadas do todo, trazem junto suas raízes. Assim, palavras do mundo fabril ou do mundo do trabalho transitam no vocabulário escolar ou educacional, não somente pela transposição de sentido para melhor dizer a respeito do objeto, mas pela ideia de similitude, aproximação que se criou entre uma e outra instituições (fábrica e escola). A migração dessas palavras significou o reconhecimento de uma instituição colocada socialmente como sendo a extensão da outra. Mas longe de conceder ao professor 
responsabilidade e autonomia, a metáfora do professor como operário trouxe implicitamente consigo a ideia de que o fim visado pode e deve ser definido em termos inteiramente objetivos, facilmente verificados por qualquer um que se situe no exterior da própria atividade: só o que importa é o resultado, o 'produto'.

Das numerosas imagens produzidas para representar a atividade do educador, hoje aquela de maior pregnância, ou pelo menos aquela sobre a qual todas as outras metáforas convergem, é a do 'professor como trabalhador'. De fato, vêm da fábrica e da indústria modernas as mais cristalizadas metáforas que elucidam o universo da educação pública escolar. Contudo, a referência central do trabalho industrial não é um fenômeno que ocorre somente na escola, muito menos é a fábrica que serve de modelo para as organizações sociais. Estamos falando de uma sociedade que retira do modelo de produção o sentido para todas as suas atividades e se organiza a partir de uma centralidade que o mundo moderno passou a dar ao trabalho, da qual a experiência fabril, por um momento histórico, tornou-se hegemônica.

Para Castoriadis (1997b), o distinguir, escolher, estabelecer, juntar, contar, dizer são modos de criação social-históricos que implicam uma conjuntificação de elementos que buscam dar ao mundo certa organização naquilo que for passível de organização, de fazer existir a sociedade, de instaurar e fazer funcionar a linguagem, de desenvolver a prática e de possibilitar aos homens se relacionarem entre si de outra maneira, distinta da fantasia. A divisão das atividades humanas como uma instituição histórico-social suficiente quanto ao uso e necessidade - definição esta que não é um processo natural, bem arbitrariamente construído socialmente pelo projeto moderno - partiu de uma perspectiva que tende a ver unidade ali onde há multiplicidade. A crítica aqui repousa sobre esse monismo que fez do trabalho uma unidade central e doadora de sentido para todas as outras atividades humanas, especialmente aquelas destinadas à formação.

Mas que outra metáfora - sem se apresentar como monopolizadora de sentido - poderia ser contraposta àquela oriunda do trabalho, operando a crítica da redução economicista que esta introduz, patente nos sentidos que os termos 'produtividade', 'racionalização', 'trabalho', 'profissão' etc. passaram a adquirir na educação, e de modo que permita vislumbrar algumas das especificidades da atividade docente?

\section{A ação docente}

Decerto, tal situação não se resolveria com a introdução de uma nova metáfora supostamente capaz de superar os limites das imagens do mundo do trabalho na educação, pois, como tentamos estabelecer anteriormente, as 
metáforas jamais esgotam os sentidos que se propõem a representar - por mais que elas tendam tão frequentemente a nos fazer esquecer disso. Mas é exatamente nesse sentido que o recurso a um novo conceito - que, por definição, opera uma abstração dos sentidos, e não de uma história de tematizações de que foi objeto - impõe-se como procedimento indispensável: espera-se que o conceito possa orientar uma ruptura, ainda que provisória, contra o fascínio da metáfora do trabalho na educação.

Tal como propõe Arendt (1987), a ação é a capacidade de começar algo novo, a capacidade de iniciativa que é reservada aos humanos. A reintrodução da distinção entre a atividade produtiva e a atividade prática supõe, antes de qualquer outra coisa, a ruptura com uma atitude que pretende submeter tudo que existe a um mesmo princípio universal e organizador: ideias, viventes e coisas podem ser identificados a um só modo de organização. Essa é a importância que a lição aristotélica guarda ainda hoje para nós: este filósofo foi o primeiro a afirmar que não era possível tratar da mesma forma objetos diferentes. A realidade se diz, ou se pensa, ou se analisa, de múltiplas maneiras (Aristóteles apud Castoriadis, 1987a), e reduzi-la a uma só tem, como vimos examinando, um custo muito grande.

O conceito de ação desvela as resistências que esse objeto muito especial - que é o elemento humano - opõe às tentativas de domesticá-lo, de dissolver sua singularidade no lugar-comum que a metáfora do trabalho na educação assegura. Pois a ação não é uma metáfora da qual se implicam os sentidos da educação. Nesse sentido, pode-se dizer que a sua adoção abre mais interrogações e hipóteses do que fornece visibilidade a seu objeto. Para o conceito, a visibilidade é o resultado de uma conquista, e não um ponto de partida.

Mas o que dá a ver o conceito? Nem tanto o que já se pensava ali encontrar, na forma familiar, mas sobretudo aquilo que ainda não se havia visto algumas franjas de realidade que o recurso abusivo às metáforas acabou por esconder.

A formação do professor poderia depender quase que exclusivamente da aquisição de um saber especializado, capaz de fixar os parâmetros necessários e suficientes para o controle da prática educativa. E comparada ao processo produtivo, a educação se tornaria mera aplicação de conhecimentos prévios que permitiriam planificar a atividade e prever seus produtos.

Contudo, muito antes da modernidade, ao menos desde Platão, nos colocamos o enigma de saber em termos contemporâneos se o bom resultado da formação é coisa que se ensina, que se adquire pelo exercício, pela prática ou de outra maneira (Platão, 2001). Entretanto, passadas algumas centenas de séculos, sobretudo em razão do desenvolvimento das ciências, não deixa de ser tentadora uma resposta que assegure a inexistência de qualquer mistério a respeito desse assunto. Obviamente, essa boa, porém 
precipitada, resposta representa, no melhor dos mundos, uma despreocupação com questões feitas pelos antigos e que nós já não mais fazemos: a possibilidade da educação.

Freud declarou que a psicanálise, a pedagogia e a política são as três profissões impossíveis (...). Freud não disse que essas profissões são difíceis, como a do neurocirurgião, do pianista de concerto ou do guia de alpinismo. E nem por isso podemos qualificá-las de impossíveis, porque lidam com o mais intratável de todos os materiais, o ser humano. Os generais, os vendedores, as prostitutas trabalham com esse mesmo material, e não qualificaríamos suas profissões de impossíveis (...). Parece que poderíamos evocar uma razão bastante forte tornando ao menos a psicanálise e a pedagogia quase impossíveis: é que ambas visam a mudar os seres humanos (Castoriadis, 1992, p. 152).

Psicanálise, pedagogia e política têm por finalidade a formação do elemento humano, nas diferentes esferas em que essa formação se efetiva: é essa condição que as singulariza em relação a todas as outras atividades realizadas pelos homens. Entendida como criação humana, a ação permite elucidar não o Ser genérico, ou um exemplar de um objeto, mas sempre um indivíduo singular. Essa é a dimensão de criação que se vê esvaziada nas imagens tradicionais e racionalistas que representam a atividade do professor.

A educação não se esgota no saber, ou nos saberes em que se baseia, mas constitui-se em atividade reflexiva e em exercício de deliberação. O saber técnico não substitui, mas, de certa forma, obriga à interrogação. Por não existirem respostas acabadas para a prática docente, o projeto de formação se faz 'interrogação explícita e ilimitada'. A esse projeto de formação reflexiva e deliberante, Castoriadis (1999) denominou projeto de autonomia - em uma acepção contudo bastante diferente daquela que serviu para qualificar as profissões clássicas, supostamente isentas de todo tipo de prestação de contas ao 'leigo', ao não especialista. Pensar a profissão docente como uma ação significa tomá-la como primeira exigência à autonomia visada para o aluno tanto quanto para o professor: esta é a base para a rejeição de um conhecimento absoluto, pretensamente capaz de responder de forma objetiva e infalível às demandas profissionais. A imagem do trabalhador isolado que, apoiado em um corpo de conhecimentos especializados, desempenha sua intervenção técnica e, em última análise, só presta contas a um conjunto de regras deontológicas fixadas, de uma vez por todas, pelo código corporativo dá lugar ao professor cuja prática de questionamento e de criação está inserida em uma comunidade de referência à qual ele presta contas.

Pela capacidade humana de iniciar algo novo, a prática de formação não é somente um processo dirigido ao outro (construção de sentidos comuns), mas também um processo de autoformação (construção de sentidos 
próprios). Desse modo, nenhum sujeito se forma sem que os sentidos publicamente oferecidos por sua cultura sejam apropriados e se tornem também sentidos próprios.

A prática docente obriga cada vez mais o professor a se colocar diante de questões que vão exigir dele a ruptura dos sentidos instituídos e a instituição de sentidos que não podem ser inteiramente determinados a priori. Levando a organização dos processos escolares ao seu último grau de racionalidade e excluindo a dimensão simbólica, representacional e afetiva da educação, a metáfora do trabalho substituiu o lugar da interrogação pelo lugar da determinação de regras seguras para a formação humana. Quando os professores submetidos a planejamentos fixos, a horários determinados e a conteúdos programados realizam suas atividades fora do que está determinado, a isto é chamado de desvio, como se o imprevisto representasse uma inabilidade na realização do planejamento.

Entendida como ação, a atividade docente se faz necessariamente uma prática coletiva, capaz de romper com o isolamento a que a metáfora do trabalho a veio submetendo. Ora, essa experiência de construção comum não é possível em uma organização escolar que trata os professores como trabalhadores, operários que devem cumprir um regime estrito de horas de trabalho semanais, dividir-se em diferentes turnos e matrículas somente para assegurar sua remuneração. Assim, o conceito de 'ação' introduz outras perspectivas para a redefinição das regras de 'trabalho' da atividade docente.

A exigência de construção comum também implica a prestação de contas, sem a qual a experiência educativa não faz sentido: trata-se de fornecer visibilidade às deliberações realizadas, de submeter sua prática ao crivo da crítica dos pares e às expectativas da sociedade, mas não de forma cega. Pelo fato de nunca se dar no isolamento, a educação visa à participação da cultura e à construção de sentidos comuns; e o professor se define não "como alguém que toma decisões racionais, mas como alguém que constrói sentidos" (Santos, 2009, p. 29). A prestação de contas surge como possibilidade de construção coletiva e também como proposta de vida para quem acredita que educar é se abrir para o mundo e para o outro; é lidar constantemente com a imprevisibilidade, que aceita que o fim do processo de formação é impreciso e provisório.

É necessário compreender que a escola não é somente um espaço de formação do aluno, mas também um lugar de formação para os próprios professores - pois ninguém, sozinho, pode deter o saber acabado sobre o processo de formação e, portanto, intitular-se especialista em formação humana. A prestação de contas na escola pode se converter em um momento privilegiado de formação coletiva.

A profissão docente existe não pela exigência de um conhecimento seguro, específico, exato e especializado sobre a formação humana, mas pela 
constituição de um projeto democrático de formação, de criação de valores, de uma formação ética, pela demanda por uma comunidade de práticas que criem maneiras para que o projeto comum de formação possa se realizar.

Cabe ao coletivo escolar estabelecer as condições políticas e éticas para que a prática docente se realize, pois a formação humana não é uma tarefa inteiramente técnica, posto que depositaria no professor todo o conhecimento sobre o humano. Além disso, a formação seria reduzida à aplicação de conhecimentos para fazer com que o outro aprendesse de maneira mais eficaz e segura (Santos, 2013). Portanto, o papel do coletivo escolar não é o de definir de uma vez por todas o que está certo ou errado na atividade docente, mas o de retomar a todo momento a consciência da dimensão fundamentalmente política da formação, uma vez que a atividade do professor não se reduz à aplicação de conhecimentos teóricos, tampouco é formulação de novos conhecimentos, mas é prática de reflexão e deliberação que servem de base para a constituição de novos saberes (Valle, 2014).

\section{Conclusão}

Não é, pois, equivocado afirmar que até hoje rondam a atividade de ensinar as velhas imagens do sacerdócio, da tia e do especialista. Por isso, a tentativa de completa racionalização da atividade que acompanhou a introdução da imagem do professor não conseguiu exorcizar inteiramente todas as demais imagens anteriormente construídas para encarnar a figura do formador.

Decerto a metáfora do trabalho serviu para alertar os professores para determinados direitos, relacionados à garantia de condições mínimas de realização da atividade. Mas, submetidas à lógica do mundo do trabalho, a atividade escolar e a prática docente perderam sua especificidade, moldando-se mais facilmente às exigências de objetivação e de produtividade que as políticas educacionais e o mercado tentam incessantemente introduzir.

A comparação da educação com o trabalho fabril trouxe para a educação maior objetivação, necessária a seu reconhecimento social. Entretanto, essa objetivação permitiu que se buscasse reduzi-la a resultados quantificáveis, desprezando cada vez mais aquilo que se constitui em seu cerne e que dificilmente se deixará apreender por metas e mensurações universais: a autoformação humana. A exigência de objetividade dos processos escolares, por exemplo, sempre será precária e provisória, não definindo nem esgotando a tarefa de educar.

Feita para atuar como artifício retórico e como exercício para expressar um sentido ausente, a metáfora do trabalho se cristalizou, eximindo os educadores de se interrogarem a respeito das consequências decorrentes da transposição do termo de um lugar para outro. Entendida como ação, a 
prática docente é mais do que um 'saber fazer', do que a aplicação de um conhecimento. A 'ação' nos mostra que a atividade docente se define também por um 'não saber'. Por esta razão, os fins da formação têm de ser sempre repensados, e a cada vez serem apresentados como projeto de atividade de construção comum, em uma perspectiva maior do que a metáfora do trabalho pode alcançar.

Resumen La exigencia de tratar directamente con la subjetividad hace que la educación presente características muy peculiares, que traspasan los límites de cualquier organización lógica. Este artículo pone en el centro de sus reflexiones los límites de la metáfora del trabajo en la educación, en su función de modelar y, así, explicar la actividad docente. Como donadora de sentido universal para las actividades humanas, la metáfora del trabajo, que no se reduce al simple desplazamiento de la palabra, sino a la trasposición de un sentido enraizado, se volvió excesiva e insuficiente para pensar la tarea de la formación humana. En tal sentido, la introducción del concepto de acción para elucidar la actividad docente surge con potencial representativo para la práctica del profesor, allí donde la metáfora del trabajo no logra realizarlo plenamente.

Palabras clave metáfora; trabajo; docencia.

\section{Notas}

1 Fundação Oswaldo Cruz, Escola Nacional de Saúde Pública Sergio Arouca, Centro de Estudos da Saúde do Trabalhador e Ecologia Humana, Manguinhos, Rio de Janeiro, RJ, Brasil.

<gidborgess@gmail.com>

Correspondência: Fundação Oswaldo Cruz, Escola Nacional de Saúde Pública Sergio Arouca, Avenida Leopoldo Bulhões, 1.480, sala 315, Manguinhos, CEP 21041-210, Rio de Janeiro, RJ, Brasil. 


\section{Referências}

ARENDT, Hannah. A condição humana. Rio de Janeiro: Forense Universitária, 1987.

ARISTÓTELES. Arte retórica e poética. Rio de Janeiro: Ediouro, 1975.

ARROYO, Miguel. Operários e educadores se identificam: que rumos tomará a educação brasileira? Revista Educação e Sociedade, Campinas, n. 5, p. 5-23, jan. 1980.

CASTORIADIS, Cornelius. Valor, igualdade, justiça, política de Marx a Aristóteles e de Aristóteles até nós. In: CASTORIADIS, Cornelius. As encruzilhadas dos labirintos I. Tradução Carmem da Silva Guedes e Rosa Maria Boaventura. Rio de Janeiro: Paz e Terra, 1987a. p. 264-335.

CASTORIADIS, Cornelius. O imaginário: a criação no domínio social-histórico. In: CASTORIADIS, Cornelius. As encruzilhadas dos labirintos II: os domínios do homem. Tradução José Oscar de Almeida Marques. 2. ed. Rio de Janeiro: Paz e Terra, 1987b. p. 233-254.

CASTORIADIS, Cornelius. Psicanálise e política. In: CASTORIADIS, Cornelius. As encruzilhadas dos labirintos III: o mundo fragmentado. Tradução de Rosa Maria Boaventura. Rio de Janeiro: Paz e Terra, 1992. p. 151-164.

CASTORIADIS, Cornelius. Phusis, criação, autonomia. In: CASTORIADIS, Cornelius. As encruzilhadas dos labirintos $V$ : feito e a ser feito. Tradução de Lílian do Valle. Rio de Janeiro: DP\&A, 1999, p. 211-222.

ENGUITA, Mariano Fernandez. A ambiguidade da docência: entre o profissionalismo e a proletarização. Teoria e Educação - dossiê: interpretando o trabalho docente, Porto Alegre, n. 4, p. 41-61, 1991.
FONTANA, Klalter B.; TUMOLO, Paulo S. Trabalho docente e capitalismo: um estudo crítico da produção acadêmica da década de 1990. Educação \& Sociedade, Campinas, v. 29, n. 102, p. 159-180, jan./abr. 2008.

OLIVEIRA, Dalila A. Política educacional e a reestruturação do trabalho docente: reflexões sobre o contexto latino-americano. Educação \& Sociedade, Campinas, v. 28. n. 99, p. 355-375, maio/ago. 2007.

PLATÃO, Mênon. Texto estabelecido e anotado por John Burnet. Tradução de Maura Iglesias. Rio de Janeiro: PUC-Rio; Editora Loyola, 2001.

RICEEUR, Paul. A metáfora viva. São Paulo: Edições Loyola, 2000.

SANTOS, Bento S. Comentário sobre a obra de Santo Agostinho. In: AGOSTINHO, Santo. De Magistro. Petrópolis: Vozes, 2009. p. 7-32.

SANTOS, Gideon B. Usos e limites da imagem da docência como profissão. Revista Brasileira de Educação, Rio de Janeiro, v. 18, n. 52, p. 11-15, jan./mar. 2013.

VALLE, Lílian. Categoria, teoria, conceito (para dizer o ser em múltiplos sentidos). Trabalho, Educação e Saúde, Rio de Janeiro, v. 6, n. 2, p. 303-320, jul./out. 2008.

VALLE, Lílian. Para além do sujeito isolado: modelos antropológicos para pensar a educação. Revista Brasileira de Educação, Rio de Janeiro, v. 19, n. 57, p. 495-512, abr./jun. 2014.

Recebido em 09/09/2014

Aprovado em 06/04/2015 